\title{
Effects of BA and Leaf Piece Orientation on Adventitious Bud Formation in Leaf Cutting of Begonia Tuberhybrida Group
}

\author{
Yukiko Shimada ${ }^{1}$, Genjiro Mori ${ }^{1 *}$, Masayuki Oda ${ }^{1}$ and Genjiro Ishida ${ }^{2}$ \\ ${ }^{1}$ Graduate School of Life and Environmental Science, Osaka Prefecture University, Naka-ku, Sakai 599-8531, Japan \\ ${ }^{2}$ Hiroshima Botanical Garden, Saeki-ku, Hiroshima 731-5156, Japan
}

\begin{abstract}
We studied the effects of the type of leaf cuttings, 6-benzylaminopurine (BA) application, and the section position and orientation of leaf pieces on adventitious bud formation in leaf cuttings inserted in rockwool beds, using expanded young leaf blades of Begonia Tuberhybrida Group 'Tenella'. In BA absence, $73 \%$ of whole leaf blades with petioles formed adventitious buds, whereas none of the $2 \times 1.5 \mathrm{~cm}$ leaf pieces did at all. The percentages of surviving and adventitious bud formation of $2 \times 1.5 \mathrm{~cm}$ leaf pieces without petioles were $47 \%$ and $0 \%$, respectively. When these small leaf pieces were inserted in rockwool beds containing 0.25-2 ppm BA, the percentages of surviving and adventitious bud formation were $100 \%$ and $80 \%$, respectively. In BA presence, the percentage of adventitious bud formation became lower from the base towards the tip of the leaf, and the leaf pieces at positions $2 \mathbf{c m}$ away from the leaf bases did not form adventitious buds at all. When they were placed horizontally and vertically inverted, the percentages of adventitious bud formation were $60 \%$ and $80 \%$, respectively.
\end{abstract}

Key Words: adventitious bud, BA, Begonia Tuberhybrida Group, leaf cutting.

\section{Introduction}

Begonia Tuberhybrida Group is traditionally propagated by seed, because vegetative propagation with cuttings is difficult. Although Iida et al. (1986), Nakano et al. (1999), Peck and Cumming (1984), and Viseur and Lievens (1987) developed systems for in-vitro propagation of $B$. Tuberhybrida Group, the systems are limited to only a few cultivars and are not practical because of the presence of endotrophic bacteria in tissue. If an adequate technique for vegetative propagation of $B$. Tuberhybrida Group is developed, which does not depend on in-vitro propagation and has a similar effect, it would be useful for commercial production.

In a previous paper (Shimada et al., 2006), we reported that rockwool beds were useful as a medium for leaf piece cuttings of Begonia Tuberhybrida Group, and that adventitious bud formation frequency was higher on the proximal parts of leaf pieces than on distal ones. However, this method resulted in about $50-60 \%$ of adventitious bud formation and was limited to the formation of a few buds per leaf. It is desirable to obtain more effective adventitious bud formation from smaller

Received; July 1, 2006. Accepted; November 10, 2006.

* Corresponding author (E-mail: gmiki@plant.osakafu-u.ac.jp). leaf pieces.

Shimada et al. (2005) previously showed that most leaf pieces perished on agar medium containing $\alpha$-naphthalene acetic acid (NAA), and the percentages of surviving and adventitious bud formation were increased by adding 6-benzylaminopurine (BA) in the absence of NAA. We anticipated that in rockwool beds, too, adventitious bud formation might be induced with a high frequency by adding BA to water for bottom irrigation.

The aim of the present work was to study the effects of BA application and the type of leaf cuttings on adventitious bud formation, and to compare the morphogenic competence of the section position from the leaf base towards the tip, in order to improve the frequencies of adventitious bud formation.

\section{Materials and Methods}

Leaf piece cuttings of Begonia Tuberhybrida Group 'Tenella' were made between July 2005 and March 2006. Leaf pieces for leaf cuttings were obtained from stock plants cultured by seeding in March 2003. After expanded young leaves were detached from these stock plants, the leaf pieces were prepared by excising the leaf blade including a main vein with or without a petiole. Each leaf piece was inserted in a rockwool bed (M25S30, Nittobo Ltd., Japan $)$ in a plastic container $(15 \times 10 \times 5 \mathrm{~cm}$ 
in height) containing $250 \mathrm{~mL}$ BA solution of different concentrations. The maximum water holding capacity of the rockwool bed was approximately $91 \%$ of its volume. The lid of the container was placed while being slightly open. Each treatment with 5 leaf pieces was replicated three times. Unless otherwise stated, after 6 weeks of insertion, leaf pieces were pulled from the rockwool beds and the numbers of survivors, adventitious buds, roots, and calli formed at the bases were counted. The leaf pieces which formed adventitious buds produced some shoots of about $3-\mathrm{mm}$ in height and tiny plural axillary buds at the base of these shoots which were difficult to count. Hence, we recorded only the percentage of leaf pieces that formed adventitious buds. All stock plants as leaf sources and leaf pieces inserted in rockwool beds in plastic containers were cultivated in a glasshouse with controlled temperature, as described later, and a photoperiod of $18 \mathrm{~h}$ extended by metal halide lamps (MF400-L-J2/BU-P, Toshiba Lighting \& Technology Corp. Japan) at approximately $150 \mu \mathrm{mol} \cdot \mathrm{m}^{-2} \cdot \mathrm{s}^{-1} \mathrm{PPF}$, and shaded natural light by $50 \%$ from May to early September.

\section{Effects of types of leaf cuttings on adventitious bud formation (Expt. 1)}

Expanded young leaves were cut in different ways, i.e., whole blades or basal $2 \times 1.5 \mathrm{~cm}$ leaf pieces of leaf blades with and without $5 \mathrm{~mm}$ petioles on 20 July 2005 . These leaf pieces were inserted vertically upright in rockwool beds containing distilled water on a bench in a glasshouse controlled at $25 / 15^{\circ} \mathrm{C}$ (day temperature/ night temperature: DT/NT).

\section{Effects of BA concentration on the adventitious bud formation (Expt. 2)}

Basal $2 \times 1.5 \mathrm{~cm}$ pieces of leaf blades without petioles were cut on 26 March 2006. The leaf pieces were inserted vertically upright in rockwool beds containing different concentrations $(0,0.05,0.1,0.25,0.5,1$, or $2 \mathrm{ppm})$ of BA on a bench in a glasshouse controlled at $25 / 15^{\circ} \mathrm{C}$ (DT/NT).

\section{Relationship between the section position of leaf} pieces and adventitious bud formation (Expt. 3)

The leaf pieces $(2 \times 1.5 \mathrm{~cm})$ were cut at $0,1,1.5$, or $2 \mathrm{~cm}$ from the bases towards the tips of leaf blades and inserted vertically upright in rockwool beds containing
$0.5 \mathrm{ppm}$ BA on a bench in a glasshouse controlled at $25 / 15^{\circ} \mathrm{C}$ (DT/NT) on 20 July 2005 . The width of the main vein at the proximal end of each leaf piece was measured and the number of vascular bundles in each main vein was counted under a light microscope at the beginning of the experiment. Five leaves were used for each observation.

\section{Effects of leaf piece orientation on adventitious bud formation (Expt. 4)}

Leaf pieces $(2 \times 1.5 \mathrm{~cm})$ cut at $2 \mathrm{~cm}$ from the leaf bases were placed vertically upright, horizontally, or vertically inverted in rockwool beds containing $0.5 \mathrm{ppm}$ of BA on a bench in a glasshouse controlled at $25 / 15^{\circ} \mathrm{C}$ (DT/NT) on 20 August 2005. After 8 weeks of insertion, they were pulled up to observe the presence or absence of adventitious buds.

\section{Results}

\section{Effects of types of leaf cuttings on adventitious bud} formation (Expt. 1)

The presence of petioles in leaf cuttings influenced survival (Table 1). No matter what the size of the leaf pieces were almost all of the pieces with petioles survived, whereas the majority of small leaf pieces $(2 \times 1.5 \mathrm{~cm})$ without petioles died after browning, and the surviving percentage was only $47 \%$.

Seventy three $\%$ of whole leaf blades with petioles formed adventitious buds. However, small leaf pieces did not form adventitious buds at all. About $100 \%$ of the surviving leaf pieces formed adventitious roots or calli.

\section{Effects of BA concentration on adventitious bud formation (Expt. 2)}

Seventy three $\%$ of leaf pieces inserted in the absence of BA survived, while $87 \%$ survived in $0.05 \mathrm{ppm}$ BA, and $100 \%$ survived with more than $0.1 \mathrm{ppm}$ (Table 2). The percentage of adventitious bud formation was $80 \%$ in the range of $0.25-2 \mathrm{ppm}$, and the buds formed on the surface of the leaf base (Fig. 1).

\section{Relationship between the section position of leaf pieces and adventitious bud formation (Expt. 3)}

The width of the main vein and the number of vascular bundles in the main vein of each leaf piece decreased with distance from the leaf base, as shown in Table 3

Table 1. Effects of types of leaf cuttings on adventitious bud formation.

\begin{tabular}{lccccc}
\hline \hline \multirow{2}{*}{ Type of cutting } & \multirow{2}{*}{$\begin{array}{c}\text { Surviving } \\
\text { percentage }\end{array}$} & \multicolumn{3}{c}{ Percentage of organ formation } \\
\cline { 3 - 6 } & & Adventitious buds & Only calli & Only roots & No change \\
\hline Whole leaf blade with $5 \mathrm{~mm}$ petiole & $100 \mathrm{~b}$ & $73 \mathrm{~b}$ & 0 & $27 \mathrm{a}$ & 0 \\
$2 \times 1.5 \mathrm{~cm}$ leaf piece with $5 \mathrm{~mm}$ petiole & $93 \mathrm{~b}$ & $0 \mathrm{a}$ & 0 & $93 \mathrm{c}$ & 0 \\
$2 \times 1.5 \mathrm{~cm}$ leaf piece without a petiole & $47 \mathrm{a}$ & $0 \mathrm{a}$ & 0 & $47 \mathrm{~b}$ & 0 \\
\hline
\end{tabular}

Cuttings of three types $(n=5)$ were inserted vertically upright in rockwool beds. Three replicates were used for each treatment. Mean separation within a column followed by Tukey's multiple range test, $P=0.05$. 
Table 2. Effects of BA concentration on adventitious bud formation of leaf pieces.

\begin{tabular}{cccccc}
\hline \hline \multirow{2}{*}{$\begin{array}{c}\text { Concentration of BA } \\
(\mathrm{ppm})\end{array}$} & $\begin{array}{c}\text { Surviving } \\
\text { percentage }\end{array}$ & Adventitious buds & Only calli & Only roots & No change \\
\cline { 3 - 6 } 0 & $73 \mathrm{a}$ & $0 \mathrm{a}$ & $0 \mathrm{a}$ & $73 \mathrm{~b}$ & $0 \mathrm{a}$ \\
0.05 & $87 \mathrm{~b}$ & $20 \mathrm{a}$ & $7 \mathrm{a}$ & $60 \mathrm{~b}$ & $0 \mathrm{a}$ \\
0.1 & $100 \mathrm{c}$ & $20 \mathrm{a}$ & $0 \mathrm{a}$ & $07 \mathrm{~b}$ & $0 \mathrm{a}$ \\
0.25 & $100 \mathrm{c}$ & $80 \mathrm{~b}$ & $20 \mathrm{~b}$ & $0 \mathrm{a}$ & $0 \mathrm{a}$ \\
0.5 & $100 \mathrm{c}$ & $80 \mathrm{~b}$ & $20 \mathrm{~b}$ & $0 \mathrm{a}$ & $0 \mathrm{a}$ \\
1.0 & $100 \mathrm{c}$ & $80 \mathrm{~b}$ & $20 \mathrm{~b}$ & $0 \mathrm{a}$ & $0 \mathrm{a}$ \\
2.0 & $100 \mathrm{c}$ & $80 \mathrm{~b}$ & $20 \mathrm{~b}$ & & 0 \\
\hline
\end{tabular}

$2 \times 1.5 \mathrm{~cm}$ leaf pieces without petioles $(\mathrm{n}=5)$ were inserted vertically upright in rockwool beds containing BA of various concentrations. Three replicates were used for each treatment. Mean separation within a column followed by Tukey's multiple range test, $P=0.05$.

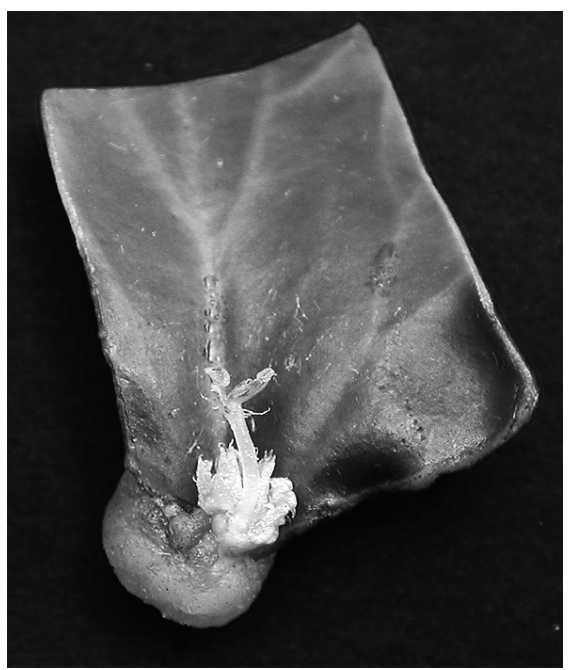

Fig. 1. Adventitious bud formed on the surface of leaf base.

\section{and Figure 2.}

The surviving percentages of leaf pieces at any distance from the leaf bases were almost $100 \%$ (Table 4). However, the percentage of adventitious bud formation was lower from the base towards the middle of the leaf, that is, the leaf pieces at $0 \mathrm{~cm}$ from the leaf base formed adventitious buds at the highest rate $(87 \%)$, followed by $1 \mathrm{~cm}(33 \%), 1.5 \mathrm{~cm}(40 \%)$, and $2 \mathrm{~cm}(0 \%)$. The greater part of leaf pieces further away from the base formed calli.
Table 3. Width of a main vein at different distances from the leaf base.

\begin{tabular}{ccc}
\hline \hline $\begin{array}{c}\text { Distance from leaf base } \\
(\mathrm{cm})\end{array}$ & $\begin{array}{c}\text { Width of main vein } \\
(\mathrm{mm})\end{array}$ & $\begin{array}{c}\text { Number of vascular } \\
\text { bundles in main vein }\end{array}$ \\
\hline 0 & $2.1 \pm 0.3$ & $5.4 \pm 0.9$ \\
1.0 & $1.4 \pm 0.2$ & $3.0 \pm 0$ \\
1.5 & $1.3 \pm 0.2$ & $3.0 \pm 0$ \\
2.0 & $1.2 \pm 0.2$ & $2.0 \pm 0.7$
\end{tabular}

${ }^{\mathrm{z}}$ Mean $\pm \operatorname{SD}(\mathrm{n}=5)$
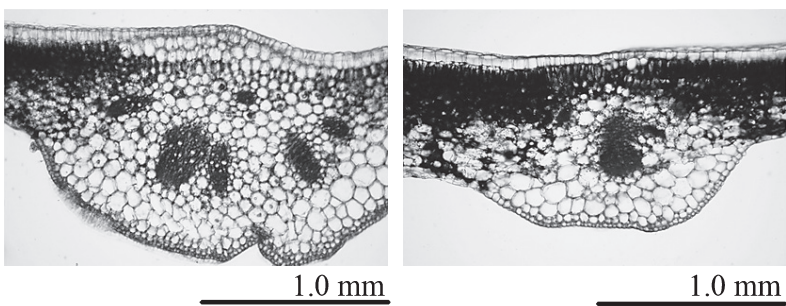

Fig. 2. Transverse section through the proximal end of a main vein in a leaf piece. Left, the base of a leaf blade; right, $2 \mathrm{~cm}$ from the base of a leaf blade.

\section{Effects of leaf piece orientation on adventitious bud formation (Expt. 4)}

The surviving percentage of leaf pieces placed horizontally was lower because of browning compared to those vertically upright, but to a small degree (Table 5).

When leaf pieces were placed vertically upright, none formed adventitious buds and most formed calli. However, when they were placed horizontally or vertically inverted, the percentages of adventitious bud

Table 4. Relationship between the section position of leaf pieces and adventitious bud formation.

\begin{tabular}{cccccc}
\hline \hline \multirow{2}{*}{$\begin{array}{c}\text { Distance from } \\
\text { leaf base }(\mathrm{cm})\end{array}$} & \multirow{2}{*}{$\begin{array}{c}\text { Surviving } \\
\text { percentage }\end{array}$} & \multicolumn{4}{c}{ Percentage of organ formation } \\
\cline { 3 - 6 } & $93 \mathrm{a}$ & $87 \mathrm{c}$ & $6 \mathrm{a}$ & 0 & $0 \mathrm{a}$ \\
\hline 0 & $93 \mathrm{a}$ & $33 \mathrm{~b}$ & $53 \mathrm{~b}$ & 0 & $7 \mathrm{a}$ \\
1.0 & $100 \mathrm{a}$ & $40 \mathrm{~b}$ & $60 \mathrm{~b}$ & 0 & $0 \mathrm{a}$ \\
1.5 & $100 \mathrm{a}$ & $0 \mathrm{a}$ & $73 \mathrm{~b}$ & 0 & $27 \mathrm{~b}$ \\
\hline
\end{tabular}

$2 \times 1.5 \mathrm{~cm}$ leaf pieces $(\mathrm{n}=5)$ at different distances from leaf bases were inserted vertically upright in rockwool beds containing $0.5 \mathrm{ppm}$ BA. Three replicates were used for each treatment. Mean separation within a column followed by Tukey's multiple range test, $P=0.05$. 
Table 5. Effects of leaf piece orientation on adventitious bud formation of leaf pieces at positions $2 \mathrm{~cm}$ away from leaf bases.

\begin{tabular}{lcrrr}
\hline \hline \multirow{2}{*}{$\begin{array}{l}\text { Orientation of } \\
\text { leaf piece }\end{array}$} & $\begin{array}{c}\text { Surviving } \\
\text { percentage }\end{array}$ & Adventitious buds (Position of buds) & Only calli & \multicolumn{2}{c}{ Percentage of organ formation } \\
\cline { 3 - 5 } & $100 \mathrm{~b}$ & $0 \mathrm{a}$ & $73 \mathrm{c}$ & 0 \\
Vertically upright & $80 \mathrm{a}$ & $60 \mathrm{~b}$ (Proximal) & $20 \mathrm{~b}$ & 0 \\
Horizontally & $87 \mathrm{ab}$ & $80 \mathrm{c}$ (Distal) & $0 \mathrm{a}$ & 0 \\
Vertically inverted & No change & $7 \mathrm{ab}$ \\
\hline
\end{tabular}

$2 \times 1.5 \mathrm{~cm}$ leaf pieces $(\mathrm{n}=5)$ were placed in rockwool beds containing $0.5 \mathrm{ppm}$ BA. Three replicates were used for each treatment. Mean separation within a column followed by Tukey's multiple range test, $P=0.05$.
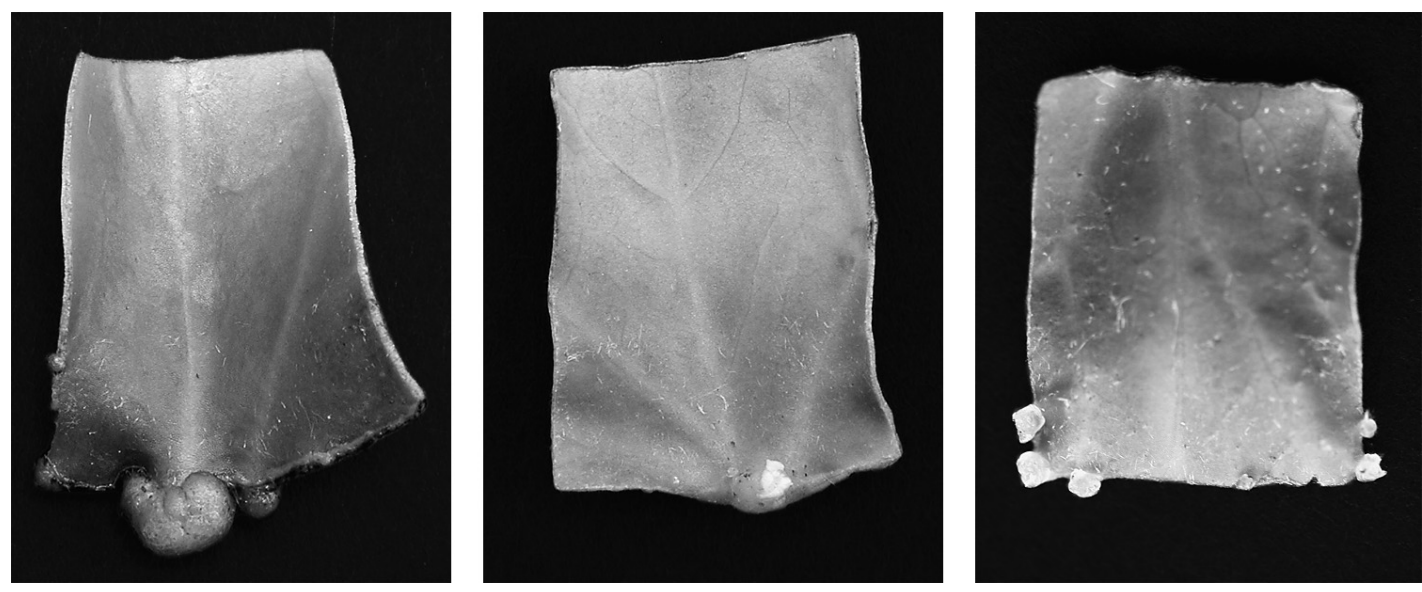

Fig. 3. Calli on a leaf piece placed vertically upright (left), adventitious buds on a leaf piece placed horizontally (middle), and vertically inverted (right).

formation were $60 \%$ and $80 \%$, respectively. Leaf pieces placed horizontally formed adventitious buds at the main vein part of the proximal cut end, and those placed vertically inverted formed small bud primordia directly without calli on some lateral veins of the distal cut end (the end immersed in the medium) (Fig. 3).

\section{Discussion}

Burritt and Leung (1996) showed that the petiole explant of Begonia $\times$ erythrophylla turned chlorotic after 14 days on a basal medium without plant growth regulators. In this study using $B$. Tuberhybrida Group, there was a tendency for small leaf pieces without petioles to become brown in the absence of BA. This may be because the wound of a small leaf piece is big for the size of the cutting and is softer than that with a petiole, and the small pieces have low contents of metabolites. The surviving percentage was increased by adding BA at more than $0.1 \mathrm{ppm}$. Beck and Camper (1991) found that the longer the delay between the time petunia explants were excised from leaves and the time they were planted on BA-containing medium, the more they become chlorotic. It is also known that BA reduces the rate of chlorophyll degradation (Costa et al., 2005). Hence, the effect of BA on small leaf piece cutting of $B$. Tuberhybrida Group is related to the suppression of chlorophyll degradation.

Whole leaf blades with petioles formed adventitious buds in $73 \%$ of cuttings even in the absence of BA. The endogenous plant hormone balance might be suitable for adventitious bud formation. However, small pieces did not form adventitious buds at all. In Expt. 2, the percentage of adventitious bud formation of small leaf pieces without petioles increased up to $80 \%$ by the addition of BA at more than $0.25 \mathrm{ppm}$. From these results, it was found that $\mathrm{BA}$ at more than $0.25 \mathrm{ppm}$ prevented the death of leaf pieces and induced the formation of adventitious buds.

The frequency of adventitious bud formation was highly dependent on the position of piece in the leaf blade; the frequency was lower from the base towards the tip of the leaf blade. No buds were formed in leaf pieces of $2 \mathrm{~cm}$ from the leaf bases. This is consistent with the results obtained by Shimada et al. (2006). Similar phenomena have been reported whereby explants of a trisected carnation petal produced shoots only from the basal area of the petal (Frey and Janick, 1991), and explants from laminar segments closest to the petiole of the apple were more regenerative than those farther away from the petiole (Welander and Maheswaran, 1992). This polarity may be related to the increased density of vascular bundles in the proximal region of the leaf, or near a petiolar region. Kouider et al. (1984), Kumar et al. (1998), and Hennayake et al. (2003) also gave an explanation in which the presence of vascular bundles was crucial for adventitious shoot formation. In the present investigation, the width of the main vein and the number of vascular bundles increased toward the leaf 
base. This increase in the density of vascular bundles near the base of a leaf blade may be responsible for the adventitious bud formation because the levels of endogenous plant hormones and metabolites passing through vascular bundles are higher. This consideration may be supported by the results of a previous study (Karam and Al-Majathoub, 2000), in which the greatest regeneration percentage was obtained in leaves with a midrib compared to completely inhibited regeneration in blade explants which did not include a midrib in wild cyclamen. Furthermore, other studies have reported that a meristematic tissue develops near the transitional zone between petioles and midribs, and the middle region of the midribs free of the transitional zone does not show activity of cell division (Oka and Ohyama, 1981), while leaves reach maturity first at the tip and subsequently in a basipetal progression (Welander, 1988). These reports indicate that the organogenic capacity for leaf regeneration increase from the middle toward the base. Although whether those cells associated with the vascular bundle tissues are the origins of meristemoids which give rise to bud primordia in $B$. Tuberhybrida Group is still poorly understood, work is in progress to confirm the histological difference in developmental patterns of shoots and calli at the base and middle tissue of a leaf blade.

In order to produce adventitious buds on pieces from the middle of leaf blades, we examined treatment with a higher BA concentration ( $5 \mathrm{ppm})$, but the leaf pieces formed only calli and not buds (data not shown). It is guessed that the competence of adventitious bud formation could not be acquired only by manipulating the exogenous cytokinin levels, but that there is a necessity of adjusting the balance between endogenous auxin and endogenous cytokinin in leaf pieces.

Therefore, in Expt. 4, the effect of the orientation of the pieces from the middle of leaf blades on adventitious bud formation was studied. The percentages of adventitious bud formation of pieces placed horizontally and vertically inverted were 80 and $60 \%$, respectively. There are reports of increased shoot production by altering explant orientation during apple culture (Zimmerman and Fordham, 1989), sweet potato culture (Gosukonda et al., 1995), and pear culture (Lane, 1979). Gosukonda et al. (1995) suggested that shoot-root polarity was defined by the basipetal movement of auxin, and disruption of this polar auxin transport by explant inversion may lead to auxin depletion.

It is known that auxin moves basipetally across the parenchyma tissue and promotes callus formation (Iino, 1994). Ljung et al. (2001) observed that there was a concentration gradient of auxin in leaf blades, i. e., the central and basal parts of $1.5 \mathrm{~cm}$ long tobacco leaves contained high levels of IAA compared to the tip and margins of the leaf blade, with intense cell division. In this study, the pieces cut at the bases of leaf blades, in the normal position of vertically upright, formed callus at a main vein of the proximal cut end and adventitious buds on the surface of the leaf base (Fig. 1), while the pieces from the middle placed in the same orientation formed only the callus there (Fig. 3). Meanwhile, the pieces from the middle placed vertically inverted formed adventitious bud primordia directly without a callus on some lateral veins of the distal cut end. Based on these results, a suitable balance of endogenous auxin and endogenous cytokinin may be established near this distal cut end, resulting in the formation of adventitious bud primordia with the disturbance of the basipetal movement of auxin by inversion and cytokinin exogenously supplied as a plant growth regulator, BA.

It was concluded that $\mathrm{BA}$ of more than $0.25 \mathrm{ppm}$ enhanced the survival and adventitious bud formation of small leaf pieces, and the frequency was highly dependent on the position of the pieces in the leaf blade, being lower from the base towards the tip. Adventitious bud formation on pieces from the middle of leaf blades was achieved by placing them vertically inverted.

\section{Literature Cited}

Beck, M. J. and N. D. Camper. 1991. Shoot regeneration from petunia leaf discs as a function of explant size, configuration and benzyladenine exposure. Plant Cell, Tiss. Org. Cult. 26: 101-106.

Burritt, D. J. and D. W. M. Leung. 1996. Organogenesis in cultured petiole explants of Begonia $\times$ erythrophylla: the timing and specificity of the inductive stimuli. J. Exp. Bot. 47: 557-567.

Costa, M. L., P. M. Civello, A. R. Chaves and G. A. Martinez. 2005. Effect of ethephon and 6-benzylaminopurine on chlorophyll degrading enzymes and a peroxidase-linked chlorophyll bleaching during post-harvest senescence of broccoli (Brassica oleracea L.) at $20^{\circ} \mathrm{C}$. Postharvest Biol. Technol. 35: 191-199.

Frey, L. and J. Janick. 1991. Organogenesis in carnation. J. Amer. Soc. Hort. Sci. 116: 1108-1112.

Gosukonda, R. M., C. S. Prakash and A. P. Dessai. 1995. Shoot regeneration in vitro from diverse genotypes of sweet potato and multiple shoot production per explant. HortScience 30: 1074-1077.

Hennayake, C. K., K. Dissanayake, N. Matsuda, T. Takasaki and T. Nakanishi. 2003. An efficient and reproducible in vitro plant regeneration from leaf discs in pear cultivars (Pyrus spp.). Plant Biotechnol. 20: 283-289.

Iida, T., K. Yabe, S. Washida and Y. Sakurai. 1986. Propagation of Begonia $\times$ tuberhybrida by tissue culture. Res. Bull. Aichi. Agric. Res. Ctr. 18: 186-190 (In Japanese).

Iino, M. 1994. Auxin. Soukan to Kussei. p. 464-490. In: N. Takahashi and Y. Masuda (eds.). Shokubutsuhorumonhandbukku Zyo (In Japanese). Baifukan, Tokyo.

Karam, N. S. and M. Al-Majathoub. 2000. Direct shoot regeneration and microtuberization in wild Cyclamen persicum Mill. using seedling tissue. Sci. Hortic. 86: 235-246.

Kouider, M., S. S. Korban, R. M. Skirvin and M. C. Chu. 1984. Influence of embryonic dominance and polarity on adventitious shoot formation from apple cotyledons in vitro. J. Amer. Soc. Hort. Sci. 109: 381-385.

Kumar, P. P., C. D. Rao and C.-J. Goh. 1998. Influence of petiole and lamina on adventitious shoot initiation from leaf explants of Paulownia fortunei. Plant Cell Rep. 17: 886-890.

Lane, W. D. 1979. Regeneration of pear plants from shoot 
meristem-tips. Plant Sci. Lett. 16: 337-342.

Ljung, K., R. P. Bhalerao and G. Sandberg. 2001. Sites and homeostatic control of auxin biosynthesis in Arabidopsis during vegetative growth. Plant J. 28: 465-474.

Nakano, M., Y. Niimi, D. Kobayashi and A. Watanabe. 1999. Adventitious shoot regeneration and micropropagation of hybrid tuberous begonia (Begonia $\times$ tuberhybrida Voss). Sci. Hortic. 79: 245-251.

Oka, S. and K. Ohyama. 1981. In vitro initiation of adventitious buds and its modification by high concentration of benzyladenine in leaf tissues of mulberry (Morus alba). Can. J. Bot. 59: 68-74.

Peck, D. E. and B. G. Cumming. 1984. In vitro propagation of Begonia $\times$ tuberhybrida from leaf sections. HortScience 19: 395-397.

Shimada, Y., G. Mori, Y. Katahara and M. Oda. 2005. The influence of BA and NAA on adventitious bud formation in leaf cuttings of Begonia $\times$ tuberhybrida. Acta Hort. 673: 537541.

Shimada, Y., G. Mori, Y. Katahara and M. Oda. 2006. Formation of adventitious buds of leaf pieces cutting of Begonia Tuberhybrida Group. J. Japan. Soc. Hort. Sci. 75: 318-322.

Viseur, J. and C. Lievens. 1987. In vitro propagation and regeneration of plants from calluses of Begonia $\times$ tuberhybrida. Acta Hort. 212: 705-709.

Welander, M. 1988. Plant regeneration from leaf and stem segments of shoots raised in vitro from mature apple trees. J. Plant Physiol. 132: 738-744.

Welander, M. and G. Maheswaran. 1992. Shoot regeneration from leaf explants of dwarfing apple rootstocks. J. Plant Physiol. 140: 223-228.

Zimmerman, R. H. and I. Fordham. 1989. Explant orientation affects axillary shoot proliferation of apple cultivars in vitro. HortScience 24: 351-352. 